\title{
A Persistent, TTX-Sensitive Sodium Current in an Invertebrate Neuron with Neurosecretory Ultrastructure
}

\author{
Ralph E. Davis a and Ann E. Stuart \\ Department of Physiology, University of North Carolina, Chapel Hill, North Carolina 27514
}

In the CNS of the giant barnacle (Balanus nubilus) a single pair of large neuronal somata (cross-commissural, or CC, cells), located near the entry of the median ocellar nerve, occasionally displays a prominent whitish luster. These somata have ultrastructure typical of neurosecretory cells: numerous Golgi complexes and abundant, large dense-cored vesicles (DCVs; size range, 75-275 $\mathrm{nm}$ ). Injection of a CC cell with cobalt tracer shows that it arborizes over a $7 \mathrm{~mm}$ length of the contralateral peripheral nerve out of which it projects. The processes of the arbor are profuse and varicose; the varicosities are packed with DCVs similar to those in the soma. Stimulation of a single $C C$ cell causes a substantial decrease in the number of DCVs and increases the incidence of clusters of small electron-lucent vesicles, as well as the occurrence of large electron-lucent vesicles and membrane-bound cisternae.

We studied ionic currents flowing across this cell's somatic membrane with a single-electrode voltage clamp. Unusual among these currents is an inward current that is blocked by TTX but is essentially noninactivating. In current clamp, this "persistent" current causes the action potential to be prolonged (seconds) if opposing outward current is blocked with 4-aminopyridine. The inward current is carried by $\mathrm{Na}$. Its amplitude depends on the external $\mathrm{Na}$ concentration, it is blockable by TTX, and it persists when the cell is bathed in Ca-free saline and/or Co. Other currents present in this cell include an outward current similar to molluscan A-current and a $\mathrm{Ca}$ current that contributes to the action potential (Stockbridge and Ross, 1986). The persistent $\mathrm{Na}$ current is partially activated at the cell's resting potential and, thus, may participate in determining the frequency of its impulse activity.

For many years, voltage-sensitive sodium channels were thought to comprise only two forms throughout the entire animal kingdom, one sensitive and one insensitive to TTX (Hille, 1984). Recently, sodium channels that lack inactivation have been described in nerve cells of both vertebrates and invertebrates (e.g., Grampp and Sjölin, 1975; Colmers et al., 1982; French and

Received June 16, 1987; revised Mar. 31, 1988; accepted Apr. 7, 1988.

This research was supported by National Institutes of Health Grant EY03347 to A.E.S. and NRSA Grant EY05900 to R.E.D. We thank Laura Fleck and Lisa Pfrogner for unfailing technical assistance and Wilma $K$. Hanton for assistance with the EM. Dr. G. Frank Gwilliam originally injected CC cells with cobalt and helped us perfect the tcchnique. Dr. John W. Moore provided invaluable guidance in the use of the voltage clamp. Finally, we wish to thank Milt Charlton for valuable comments on an earlier version of the manuscript.

Correspondence should be addressed to Dr. Ann E. Stuart, Department of Physiology, Med. Res. Bldg. 206H, University of North Carolina, Chapel Hill, NC 27514.

a Present address: University of Wisconsin-Madison, Department of Zoology, Zoology Research Building, 1117 W. Johnson St., Madison, WI 53706.

Copyright (c) 1988 Society for Neuroscience $0270-6474 / 88 / 113978-14 \$ 02.00 / 0$
Gage, 1985; Stafstrom et al., 1985). In some cases, this "persistent" sodium channel has a finite conductance at the cell's resting potential, and it has been suggested that it may influence the resting impulse activity of the neuron (French and Gage, 1985).

We describe here a persistent sodium channel in a pair of large, identifrable neurons (cross-commissural, or CC, cells) of the barnacle's nervous system that appear to be neurosecretory. These cells originally received attention because of the geometry of their processes and arbors, which is especially suitable for study with optical methods (Ross et al., 1986). Stockbridge and Ross (1986) also found that axons of CC cells have a calcium conductance so large that regenerative calcium-dependent voltage changes can actually propagate along them.

We present here ultrastructural observations indicating that $\mathrm{CC}$ cells are neurosecretory and that they release material from varicosities forming a plexus within a peripheral nerve. By voltage clamping their somata, we have observed the persistent $\mathrm{Na}$ current and a transient outward current resembling molluscan A-current (Conner and Stevens, 1971) in these cells. This constitutes the first report, to our knowledge, of a persistent sodium channel in a cell suspected to be neurosecretory.

Aspects of this work have been reported in abstracts (Davis and Stuart, 1985, 1986).

\section{Materials and Methods}

Specimens of the giant barnacle, Balanus nubilus, were obtained from Charles Eaton, Friday Harbor, Washington, and maintained in a recirculating aquarium at $10-15^{\circ} \mathrm{C}$. Dissection involved removal of the CNS, including the supraesophageal ganglion (SEG), the median ocellus, median ocellar nerve (MON), and long lengths of the bilaterally symmetric antennular nerves (AN). In most respects the dissection was similar to that described by Hudspeth and Stuart (1977).

Light and electron microscopy. The dissected nervous system was fixed for $1.5-3 \mathrm{hr}$ in $250 \mathrm{~mm}$ glutaraldehyde, $510 \mathrm{~mm} \mathrm{NaCl}, 90 \mathrm{~mm}$ sucrose, $100 \mathrm{~mm}$ phosphate buffer ( $\mathrm{pH} 7.4$ ) at $3-5^{\circ} \mathrm{C}$. It was immediately transferred to a postfix consisting of $30 \mathrm{mM} \mathrm{OsO}_{4}$ and $80 \mathrm{~mm}$ glutaraldehyde in the same buffered saline for $1-1.5 \mathrm{hr}$ at $3-5^{\circ} \mathrm{C}$. After a water rinse, the tissue was dehydrated in a graded ethanol series and passed through acetone before embedding in a 3:4 Epon 812:Araldite 506 plastic mixture. Glass knives were used to cut $1 \mu \mathrm{m}$ sections for light microscopy and thin sections in the silver to gold range of interference colors. Electron microscopic sections were collected on uncoated copper grids, stained with aqueous uranyl acetate and lead citrate, and examined with a Zeiss EM-10 CA EM.

For marking with Co tracer, cells were injected with $125 \mathrm{~mm}$ cobaltic hexamine chloride (made up in distilled water). Depolarizing current pulses (500 msec; $20-90 \mathrm{nA}$ ) were delivered at $1 \mathrm{~Hz}$ for $40-90 \mathrm{~min}$. The preparation was stored at $3-5^{\circ} \mathrm{C}$ for $12-24 \mathrm{hr}$ to allow Co diffusion from the somatic injection site into the distal processes of the cell. For light microscopy, the Co was then precipitated with ammonium sulfide, processed with the Timm's silver-intensification procedure, dehydrated, cleared, and mounted (technique modified from Bacon and Altman, 1977). For electron microscopy of Co-filled processes, a $5 \mathrm{~min}$ ammonium sulfide precipitation step was carried out approximately 1-5 min into the glutaraldehyde fixation. Thick sections $(1-2.5 \mu \mathrm{m})$ were 
cut from embedded material and Timm's-intensified on coverslips using $5 \% \mathrm{AgNO}_{3}$ in Timm's reagent for 7-10 min [techniques modified from Phillips (1980), Tyrer and Bell (1974), and Bacon and Altman (1977)]. These sections were then reembedded, thin-sectioned, and treated for electron microscopy as described above.

Physiology. The dissected nervous system was pinned out in a Sylgardlined chamber and superfused with normal barnacle saline: $462 \mathrm{~mm}$ $\mathrm{NaCl}, 8 \mathrm{mM} \mathrm{KCl}, 20 \mathrm{mM} \mathrm{CaCl} 2,12 \mathrm{~mm} \mathrm{MgCl}_{2}$, and $10 \mathrm{~mm}$ Tris(hydroxymethyl)aminomethane- $\mathrm{HCl}$ buffer at $\mathrm{pH}$ 7.7. Temperature was maintained at approximately $10-12^{\circ} \mathrm{C}$.

To facilitate removal of the ganglionic sheath and microelectrode penetration, the ganglion was immersed in $3 \mathrm{mg} / \mathrm{ml}$ pronase (No. 53702 , from Calbiochem-Behring Corp., La Jolla, CA) for $2 \mathrm{~min}$. It was then thoroughly washed in normal saline and the sheath removed with fine forceps. Stockbridge and Ross (1986) used $1 \mathrm{mg} / \mathrm{ml}$ pronase treatments of 8-10 min duration; they reported no obvious difference in the physiological properties of these cells (resting potentials, action potentials, and general activity) when the ganglion was desheathed with and without enzyme treatment. In animals prepared for electron microscopy, either no pronase was used, and the nervous system was immediately immersed in cold fixative upon removal from the animal, or, in the case of Co injections, a double-chambered bath was used and pronase treatment was applied only to the ganglionic compartment, sparing the antennular nerves.

Glass microelectrodes were filled with $3 \mathrm{M} \mathrm{KCl}$ and had resistances of 6-12 M $\mathrm{M}$ in the voltage-clamp experiments or 60-100 M $\Omega$ in currentclamp experiments. All intracellular recordings were made from cell somata.

A single-electrode voltage-clamp circuit (modified from Wilson and Goldner, 1975) built in the laboratory of Dr. John W. Moore (Dept. of Physiology, Duke University) was used for both current-clamp and voltage-clamp records. The voltage-clamp circuit employs a $50 \%$ duty cycle with a controllable clock period of $0.45-1.6 \mathrm{msec}$. Microelectrode capacitance compensation was carefully set to avoid potential capacitance-related artifacts. As is frequently the case in single electrode clamp situations, we are limited in the quantitative precision of our results since we are unable to constrain our cells to complete isopotentiality. Clamp speed limitations (in particular, the settling time of the clamp) require us to be cautious in interpreting the very fast (and frequently uncontrollable) currents at the onset of voltage steps; however, the prolonged and steady-state currents that were the principal objects of this study were easily resolved. Considerations relevant to the use of single electrode voltage clamps have been discussed elsewhere (e.g., Finkel and Redman, 1985).

A Nicolet digital oscilloscope provided analog-to-digital conversion and display of the current and voltage patterns. The data in the Nicolet memory was transferred to a PDP-11/23 computer (Digital Equipment Corporation) for analysis and plotting. For recording long-term activity, a Gould chart recorder was run in parallel with the above equipment.

Extracellular recordings of activity in the antennular nerve contralateral to the impaled soma were commonly made so as to monitor overall activity changes and confirm identification of the cell.

Co saline was made by replacing all of the $\mathrm{Ca}$ with $\mathrm{Co}$. In salines with reduced $\mathrm{Na}$, Tris replaced $\mathrm{Na}$. 4-AP and TTX were obtained from Sigma Chemical Co. (St. Louis, MO).

\section{Results}

Morphology of CC cells

Topography of CC cells

The CC cells are a pair of bilaterally symmetric cells located on the anterior medial margin of the dorsal surface of the supraesophageal ganglion near the root of each antennular nerve (Fig. $1, A, B)$. Occasionally these cells exhibit a reflective opalescence under direct illumination that causes them to stand out noticeably from the other cells in the ganglion (Fig. 1A). This whitish luster has been seen in the soma alone (Fig. 1A) or also extending into the axon. The reflectance of CC cells varies on a continuum from that of the translucence of ganglion cells in general to an opaque whiteness that is highly distinctive. The consistent position, large size $(60-100 \mu \mathrm{m})$, and characteristic pattern of synaptic and action potential activity of CC cells are the cues used to identify them when they are not in their white phase.
Injection of fluorescent dyes by Ross and colleagues (Ross et al., 1986; Stockbridge and Ross, 1986) has shown that the main axon of the CC cell, after forming a dense ipsilateral arbor near the soma, crosses the commissure connecting the hemiganglia. In the contralateral hemiganglion it branches to form another arbor and finally projects out the contralateral antennular nerve (Fig. $1 B$ ). Intrasomatic injection of a CC cell with Co tracer reveals that its axon terminates within the contralateral antennular nerve in a profusion of slender processes punctuated with numerous, small en passant varicosities (Fig. 1C). The primary axon (10-20 $\mu \mathrm{m}$ diameter) and its larger branches ( $>5 \mu \mathrm{m}$ diameter) are restricted to the first $4-5 \mathrm{~mm}$ of the nerve (total antennular nerve length, 20-25 mm). The arborization of fine, varicose processes overlaps the primary axon and its branches, extending from approximately $1 \mathrm{~mm}$ to about $8 \mathrm{~mm}$ out the nerve.

It is difficult to determine the precise extent of the arbor. The number of stained varicose branches diminishes over the last 2 $\mathrm{mm}$ of this arborization (Fig. $1 D$ ). Further out, although no Co staining is observed, thin sections show occasional profiles with ultrastructure similar to that of CC cell (described below); thus, it is possible that the arbor is not completely filled by the Co. On the other hand, extracellular recordings show that the $\mathrm{CC}$ cell's extracellular spike is not recorded beyond $8-10 \mathrm{~mm}$ out from the nerve, suggesting that the Co fills may reflect the total extent of the arbor.

Unlike neurosecretory cells in many other invertebrates (for reviews, see Gupta, 1983; Orchard and Loughton, 1985), CC cell processes do not terminate in a neurohemal organ, nor do they end selectively in or near the sheath surrounding the nerve in which they travel. From viewing successive focal planes through nerve whole mounts, one has the impression that $\mathrm{Co}-$ filled processes and varicosities occur throughout the depth of the nerve. Cross sections of the nerve examined in the EM corroborate this finding (see Fig. $3 A$ ).

\section{Ultrastructure of the CC cell's soma}

The whitish luster of its soma, and its diffuse arbor within the nerve, suggested that the $\mathrm{CC}$ cell might be neurosecretory. Indeed, its ultrastructure is typical of neurosecretory cclls. Lowpower electron micrographs of the soma reveal a dense cytoplasmic matrix marked by abundant small-diameter mitochondria and dense-cored vesicles (DCVs). Even in thick $(1 \mu \mathrm{m})$ sections this exceptional cytoplasmic density allows one to easily distinguish the $\mathrm{CC}$ cell within the ganglion. Numerous Golgi structures are seen in the CC cell's soma. Figure $2 A$ shows a Golgi apparatus appearing to produce a $\mathrm{DCV}$, an observation also made in many other neurosecretory preparations (see review by Orchard and Loughton, 1985). In one of the two thinsectioned somata, Golgi structures and nearby DCVs occurred in consistent, close association with small patches of glycogen (Fig. 2B).

Ultrastructure of the antennular nerve in the region of the $\mathrm{CC}$ cell's arbor

Cross sections of the antennular nerve approximately $4 \mathrm{~mm}$ from the ganglion reveal numerous DCV-loaded profiles distributed throughout its depth. Large, DCV-laden profiles approximating the sizes of the main axon and primary branches of Co-filled CC cells were observed. Figure $3 A$ shows a profile (large arrow) whose diameter is approximately that of a primary branch of the CC cell. The profile has dense cytoplasm like that 

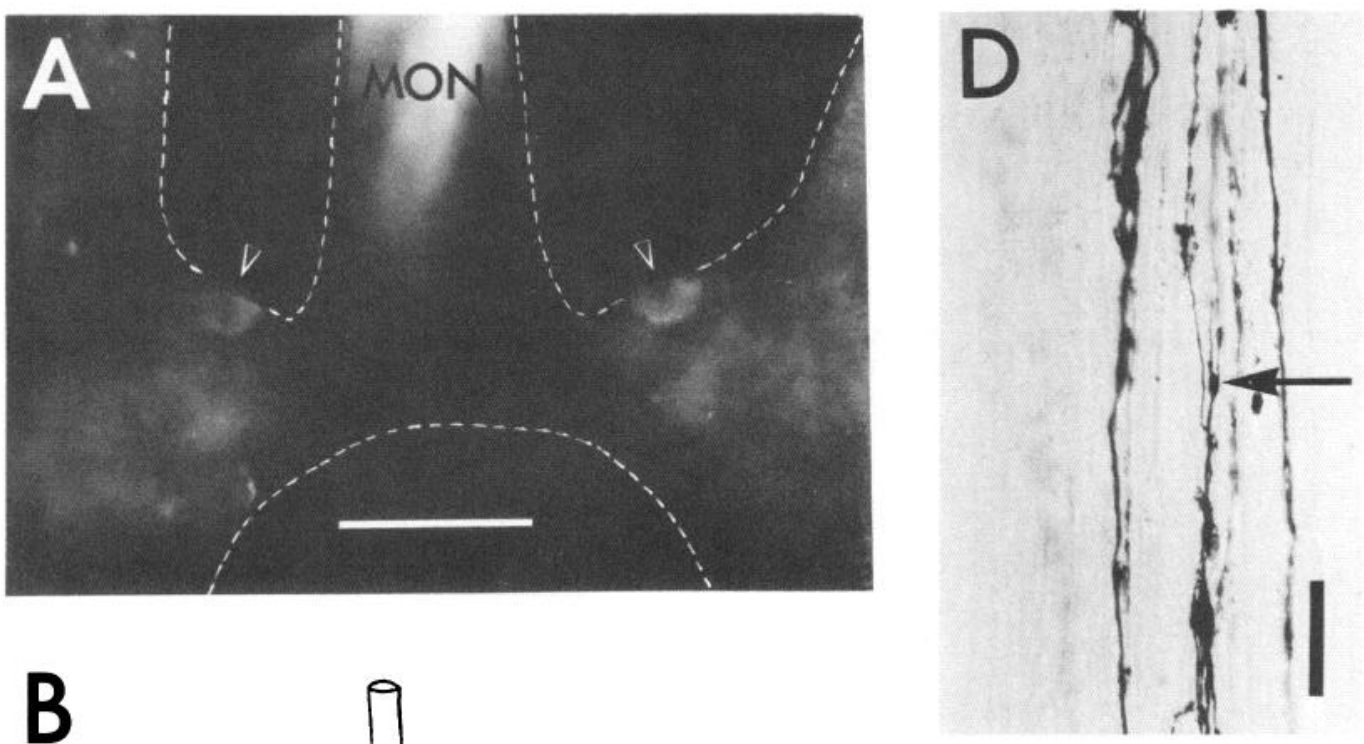

B

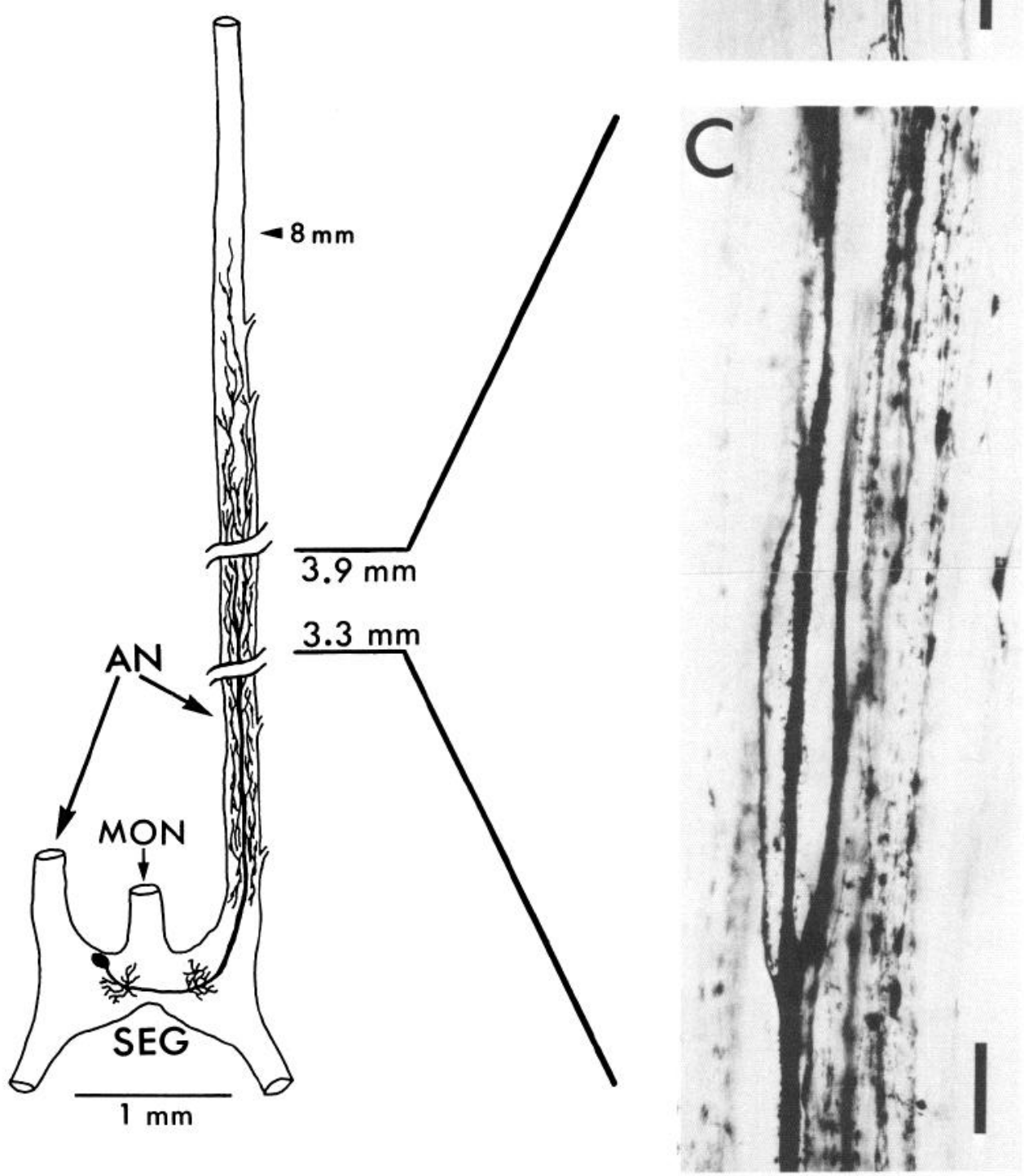

Figure 1. Position of CC cell somata and arbors in the supraesophageal ganglion (SEG) and antennular nerves (AN). A, Whole mount of the ganglion showing medial position of CC cell somata (arrowheads) on each side of the commissure connecting the 2 hemiganglia. The ganglion is illuminated directly, causing the cells to have a whitish appearance. The 2 antennular nerves exit the ganglion to the right and left of the median ocellar nerve $(M O N)$. Scale bar, $250 \mu \mathrm{m}$. B. Schematic drawing illustrating the general morphology of one of the CC cells: The position of its soma in the ganglion and of its axonal ramification in the antennular nerve. $C$, light micrograph of a portion of the cell's arborization in a whole mount of the antennular nerve approx. 3.3-3.9 mm from the ganglion, as illustrated in $B$. The cell was filled with Co. The point at which the main axon subdivides is shown; in this area are many fine branches with varicosities. Blurred dark images are processes and varicosities that are not in this 
of the CC cell's soma and numerous, large DCVs congregated toward the periphery of the profile. A smaller-diameter profile containing similar vesicles and approximating the size of varicosities in Co-filled whole mounts is also seen (small arrow). This micrograph shows the typical relationship of such vesiclemarked profiles to the overall topography of the nerve: They lie within the nerve's fascicles, among glial and other neuronal profiles. Longitudinal sections through the nerve (Fig. $3 B$ ) reveal that the vesicle-containing neurites shrink at intervals into thin necks connecting expanded varicosities. In most of these longitudinal profiles, the varicosities are packed with DCVs, while the intervening neurite contains few or no vesicles (Fig. $3 B$ ). Occasionally the vesicles are lined up, as if along a microtubule or neurofilament (Fig. 3C).

The DCVs are membrane-bound (Fig. $3 D$ ) and range in diameter from approximately 75 to $275 \mathrm{~nm}$. The size and appearance of these vesicles are similar to those found in neurosecretory cells of other organisms (e.g., Price and McAdoo, 1979; Haskins et al., 1981; see reviews by Chaigneau, 1983; Orchard and Loughton, 1985; Sedlak, 1985). A few smaller, clear vesicles (approximately $20-60 \mathrm{~nm}$ in diameter) and mitochondria are also seen in these profiles (Fig. $3 D$ ). Though extremely rare, omega-forms have been observed in the membrane of the varicosities, indicating possible sites of release (Fig. $3 D$, arrow).

There is no obvious postsynaptic target for the material suspected of being released from the DCV-filled varicosities. Postsynaptic densities or widened clefts, which would indicate synapses, are not seen (Fig. 3D). There are no obvious channels, such as enlarged extracellular spaces surrounding these profiles, to conduct released material out of the nerve to the hemolymph (Fig. $3 A$ ). It appears that material may simply be released locally into the extracellular space of the nerve itself.

\section{Equivalence of DCV-containing profiles with those of the $C C$ cell}

To determine whether the profiles containing DCVs belong to the $\mathrm{CC}$ cell, the arbors of cobalt-filled CC cells were examined. Dense cobalt-silver precipitates occurred selectively over certain large and small profiles. The larger of these profiles $(>5 \mu \mathrm{m})$, the axon and primary branches of the $\mathrm{CC}$ cell, were filled with the dense precipitate that often obscured the ultrastructure. In the smaller profiles $(1-5 \mu \mathrm{m})$, the ultrastructure was not obscured and DCVs were obvious, intermingled with the clumped precipitate (Fig. 4). These vesicles are of the same size range (75$275 \mathrm{~nm}$ ) and general appearance as those seen in profiles from unfilled preparations (Figs. 2, 3).

In preparations in which the $\mathrm{CC}$ cell had been filled with $\mathrm{Co}$, precipitate also was found in the tissue surrounding DCV-containing profiles (Fig. 4), but appeared to be nonspecific since the granules were smaller, not clumped, and evenly distributed (except for a curious absence from the deep interior of profiles of adjacent neurons).

To determine whether the CC cell accounts for all DCVcontaining profiles in the nerve, we counted profiles in cross sections of one preparation containing clumped precipitate and DCVs. Of 24 profiles containing DCVs, 16 (or $67 \%$ ) also contained precipitate. While uneven distribution of the tracer could
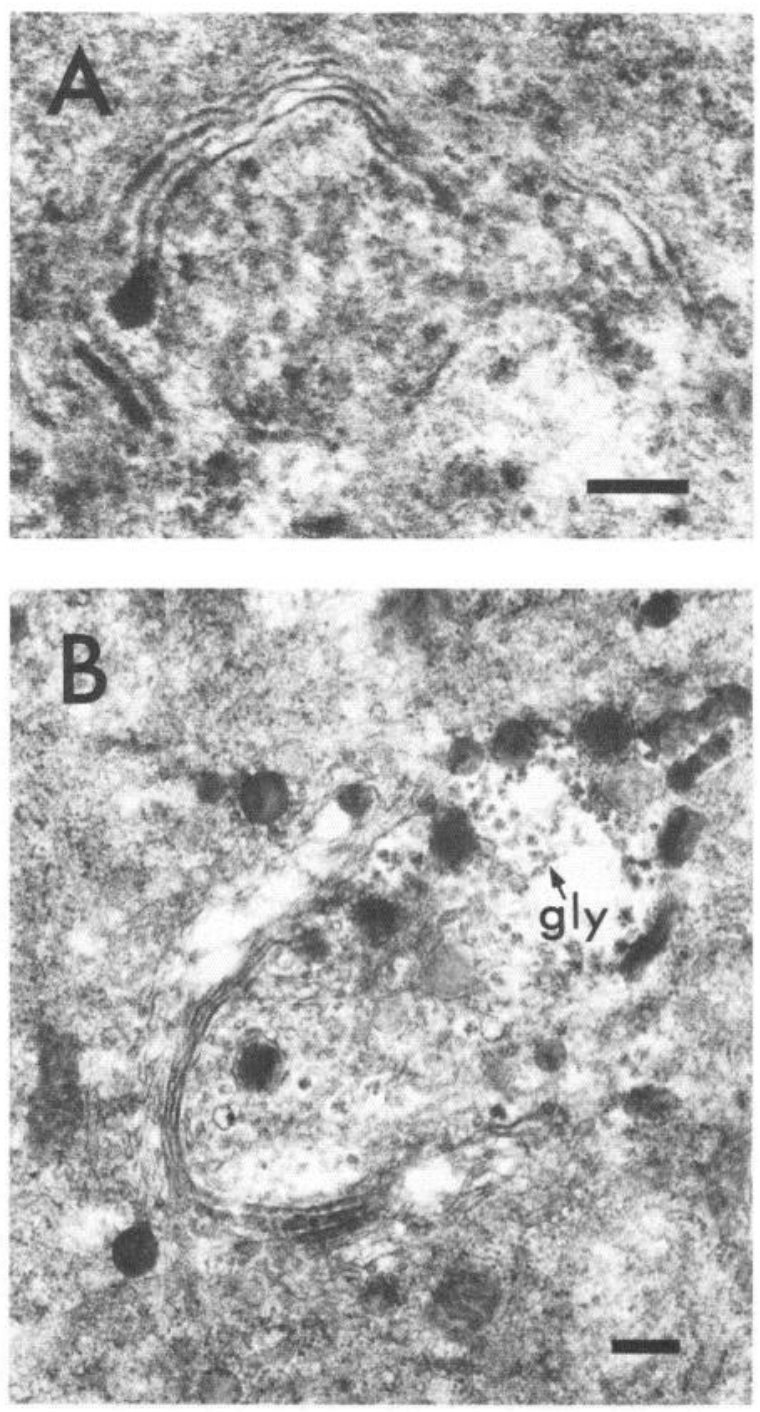

Figure 2. Ultrastructure of the CC cell's soma. $A$, Golgi complex from soma of CC cell. Numerous such complexes are seen terminating in dense-cored buds. Scale bar, $250 \mathrm{~nm}$. B, Lower-power view of Golgi from another soma illustrating the close association of these complexes with dense-cored vesicles and glycogen particles $(g l y)$. Scale bar, 250 nm.

result in CC cell profiles that showed no precipitate, these results suggest that there may be other neurons in the antennular nerve containing DCVs. In contrast, 9 out of $10 \mathrm{DCV}$-laden profiles showed ultrastructural changes when the CC cell was stimulated (see below), suggesting that most or all of the DCV-containing profiles belong to the $\mathrm{CC}$ cell or cells responding to its stimulation.

\section{Changes in the ultrastructure of $D C V$-containing profiles with stimulation}

As has been shown for other neurosecretory cells (e.g., Haskins et al., 1981), it is possible to deplete the varicosities of a large portion of their DCVs by electrical stimulation. A CC cell's soma was stimulated intracellularly at a frequency intended to mimic spontaneous bursting activity (see Fig. 5 for stimulus

focal plane. Scale bar, $50 \mu \mathrm{m} . D$, Photomicrograph of the same nerve further out (approx. $6 \mathrm{~mm}$ from the ganglion), where the meshwork is less dense. A fine varicose process is marked by an arrow. Scale bar, $50 \mu \mathrm{m}$. 

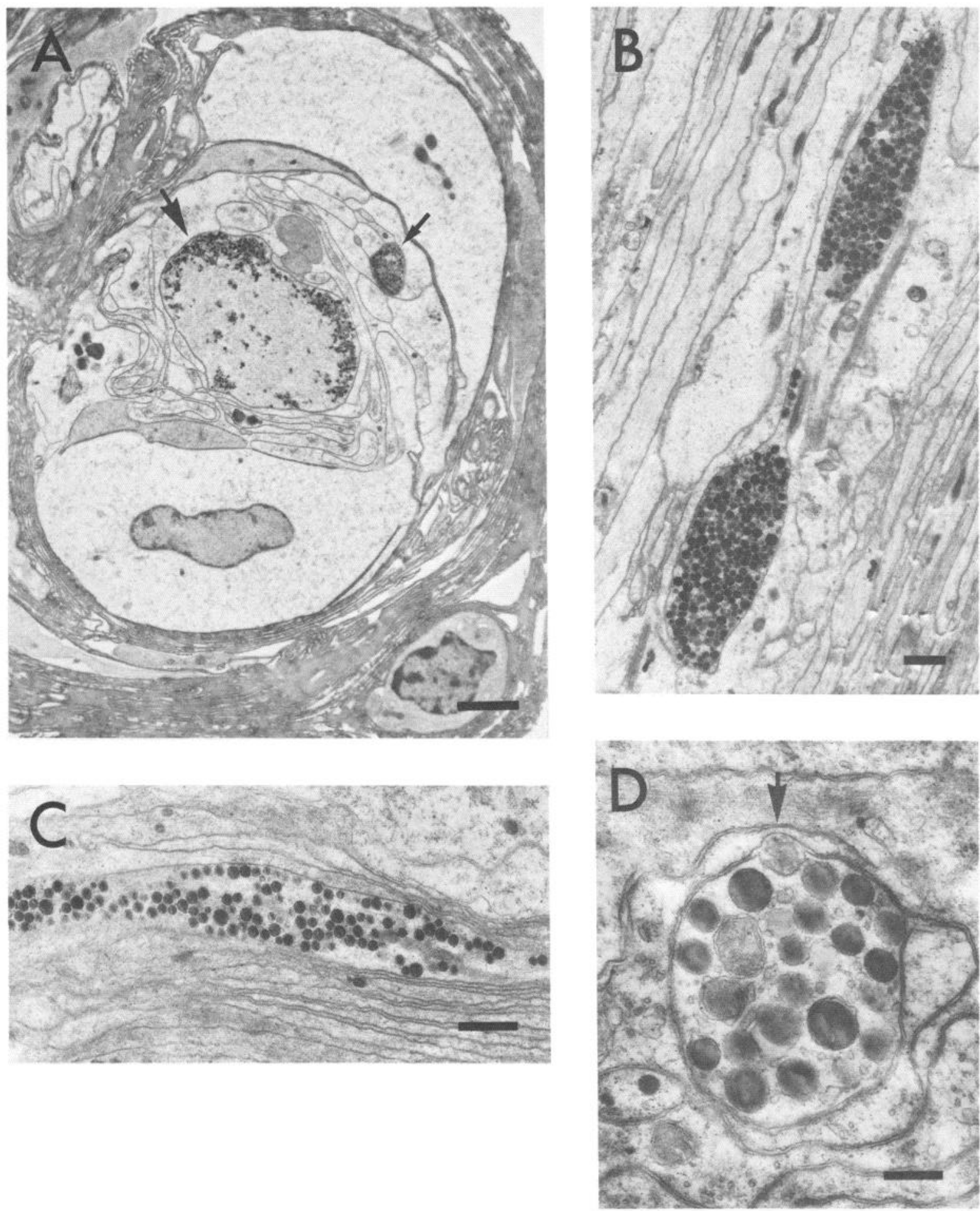

Figure 3. Ultrastructure of profiles containing dense-cored vesicles in the antennular nerve. $A$, Cross section of a fascicle of the antennular nerve $4 \mathrm{~mm}$ from the ganglion. The profile indicated by the large arrow contains dense-cored vesicles around its periphery. The small arrow indicates a smaller profile containing dense-cored vesicles. Scale bar, $2 \mu \mathrm{m}$. B, Longitudinal section showing 2 varicosities connected by a thin neurite. Vesicles are characteristically absent or present in very small numbers in the neck connecting varicosities. Scale bar, $1 \mu \mathrm{m}$. $C$, Longitudinal sections occasionally reveal varicosities with vesicles arranged in what appear to be linear arrays. Scale bar, $1 \mu \mathrm{m}$. $D$, Cross section of a vesicle-containing varicosity. Large, membrane-bound dense-cored vesicles and small clear vesicles are apparent. Arrow indicates omega-form where large vesicle appears to be releasing its contents into the extracellular space. Scale bar, $250 \mathrm{~nm}$.

details). Fixation within 1-10 min of stimulation resulted in profiles with fewer DCVs (Fig. $5 A$ ) than in DCV-filled profiles from the contralateral antennular nerve (cf. profiles belonging to the unstimulated CC cell in Fig. 5D).
Stimulated profiles also had a higher incidence of electronlucent vesicles than unstimulated ones. While these vesicles included all sizes between small "microvesicles" (approx. 20$60 \mathrm{~nm}$ ) and large clear vesicles approximating or even slightly 


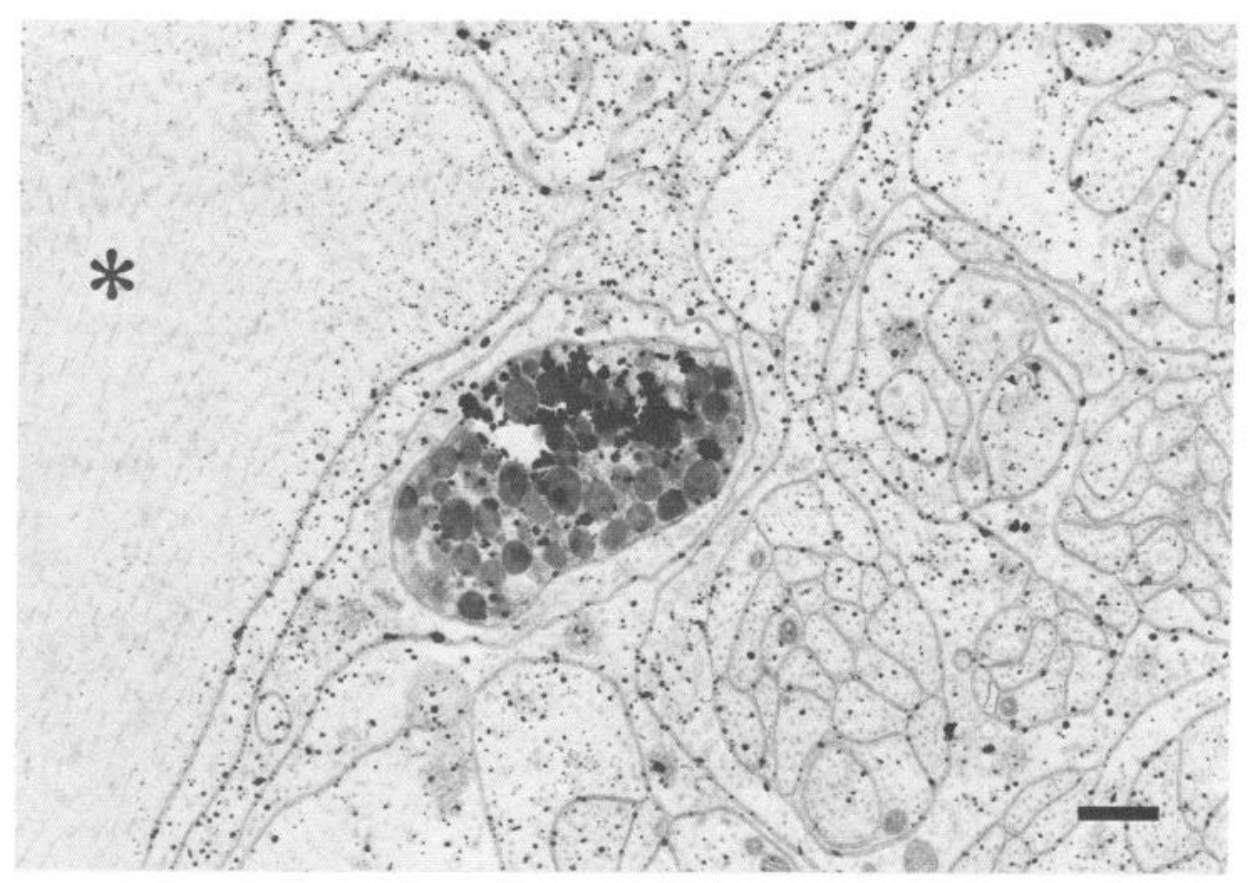

Figure 4. CC cell profile in antennular nerve identified by Co tracer. Co was injected into the soma and allowed to diffuse throughout the cell. Profile is from cross section of nerve roughly 4 $\mathrm{mm}$ from the ganglion. Clumped precipitates of cobalt-silver are located over this profile, which is filled with large dense-cored vesicles. With the exception of the large neuronal profiles whose interiors are devoid of precipitate $\left({ }^{*}\right)$, the surrounding tissue shows nonclumped, evenly distributed precipitate. Scale bar, $0.5 \mu \mathrm{m}$. larger than the size of the DCVs (up to $300 \mathrm{~nm}$ ), the two most prominent populations were the small and large vesicles. Figure 5, $A$ and $C$, illustrates the smaller ones, which were distinct because they frequently occurred in clusters within varicosities. The large clear vesicles, while observed in the small varicosities, appeared to be even more prominent in profiles larger than the typical varicosity ( $>3 \mu \mathrm{m}$; Fig. $5 B$ ), up to and including neurites approximating the primary axon in diameter. Around the periphery of the interior of the large clear vesicles a grayish substance may be seen, and in the center sporadic fine densities. Large membrane-bound cisternae were also frequently observed in the stimulated varicosities (Fig. 5C).

\section{Physiology of CC cells}

\section{Action potentials}

Like many neurosecretory cells from invertebrates, CC cells frequently give rhythmic, patterned bursts of impulses. Often a slow ramp potential leads to one or more spikes (Fig. $6 A$ ), although in some cells the firing is more steady (Fig. 7, $A$ and $B$ ). The resting potential of the cell is low $(-40$ to $-50 \mathrm{mV})$, as also observed by Stockbridge and Ross (1986). Spontaneous inhibitory synaptic potentials often occur during the cell's activity (Figs. $6 A ; 7, A, B$ ) but do not participate in generating bursting rhythms. The offset of light can also transiently inhibit the cell.

Ross and Stockbridge (personal communication) have observed that spontaneous CC cell spikes recorded intrasomatically are noticeably longer in duration than somatically recorded spikes in many other neurons of the barnacle. Our recordings of spontaneous or evoked spikes in the region of the CC cell's antennular nerve arborization reveal that the CC cell's extracellular spike exhibits similar broadness, being 2-3 times the duration of typical non-CC cell spikes in the nerve (Fig. $6 B$ ).

The rising phase of the action potential has been shown to have both a $\mathrm{Na}$ and $\mathrm{Ca}$ component (Stockbridge and Ross, 1986). Figure $6 C$ presents a typical action potential elicited in normal saline by a short intracellular current pulse. When the
$\mathrm{Ca}$ in the saline is replaced by $\mathrm{Co}$, the cell still gives an impulse; when 4-AP is added to the Co saline to block outward current (see below), this impulse is prolonged into a depolarization lasting several seconds (Fig. $6 D$ ). In $\mathrm{Co} / 4-\mathrm{AP}$ saline, we have also observed spontaneous depolarizations of very long duration (20$30 \mathrm{sec}$ ). The prolonged depolarization elicited by a current pulse is reversibly abolished by TTX (Fig. $6 E$ ), as are the spontaneous depolarizations. These results indicate that the prolonged depolarizations, elicited or spontaneous, are due to a $\mathrm{Na}$ current (since $\mathrm{Co}$ is replacing external $\mathrm{Ca}$ ) that must inactivate extraordinarily slowly or not at all.

The addition of TTX to the saline frequently leads to a hyperpolarization (approximately $10 \mathrm{mV}$ in the cell of Fig. $6 C-E$; see also Fig. $7 \mathrm{~A}$ ). A likely explanation of this observation is that a TTX-sensitive current contributes to the resting potential (see below). We localize this current to the CC cell itself (and not to a TTX-sensitive tonic presynaptic input to $\mathrm{CC}$ cell) since the current can be demonstrated in CC cells when synaptic transmission has been blocked by Co (cf. the current-clamp experiment of Fig. $6 C-E$ and voltage-clamp experiments described below; see Fig. 9). As would be expected if the TTX-blockable current is carried by $\mathrm{Na}$, reduced $(50 \%) \mathrm{Na}$ also hyperpolarizes the cell (Fig. 7B). Prior to complete block of the spikes either by TTX or reduced $\mathrm{Na}$, a gradual decline in the spontaneous rate of spiking frequently occurs.

\section{Outward A-currents}

The somata of CC cells were voltage clamped (with a single electrode) with the aim of observing the TTX-blockable current predicted from the current-clamp experiments of Figure 6. In voltage clamp, the most obvious current evoked by moderate depolarizations (to -30 or $-40 \mathrm{mV}$ ) is an early transient outward current (Fig. 8), which is similar to the A-current described in molluscan neurons (Connor and Stevens, 1971; Neher, 1971; see review by Thompson and Aldrich, 1980). Depolarizations to more positive potentials evoke a strong inward current lasting $10-20 \mathrm{msec}$ (which cannot be controlled by the clamp) and a 

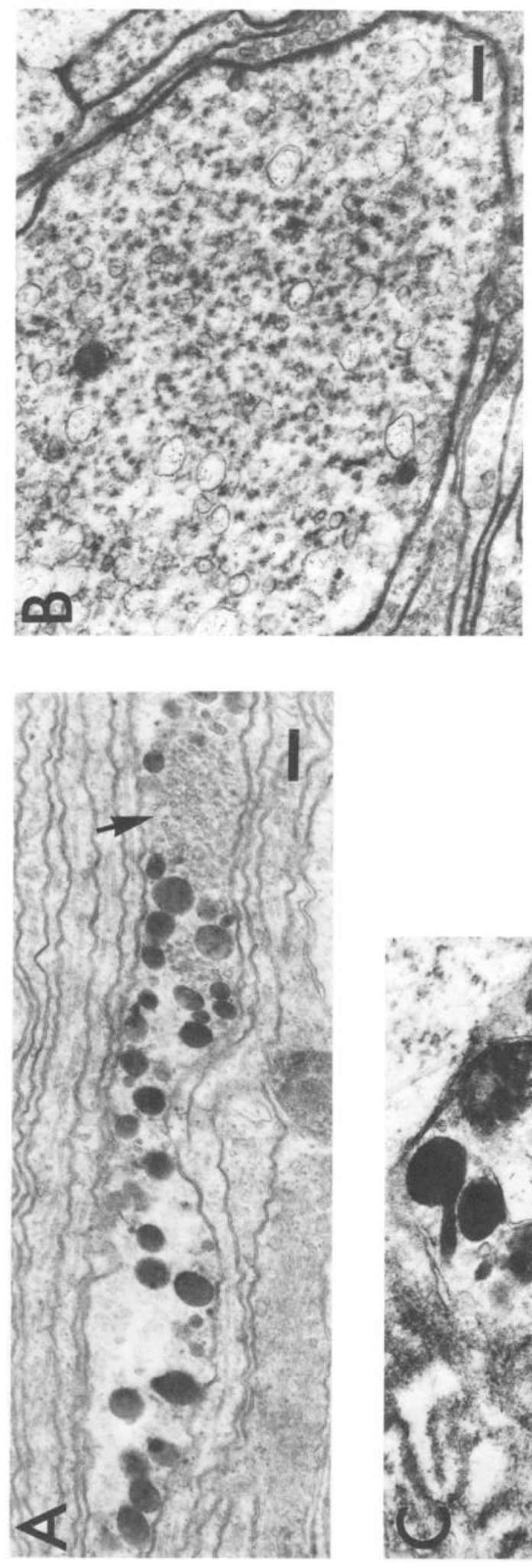
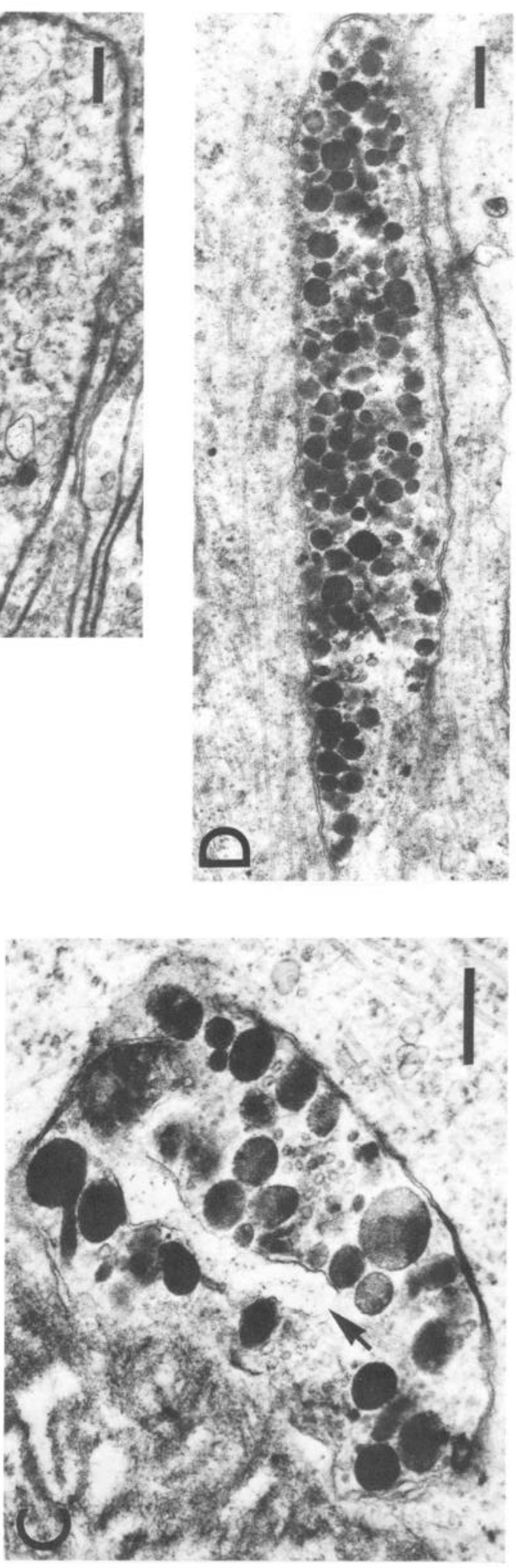

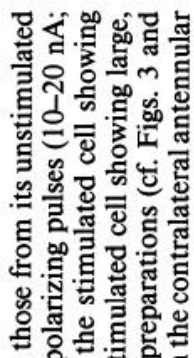

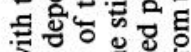

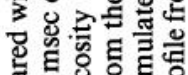

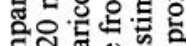
앙

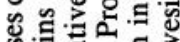

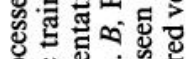

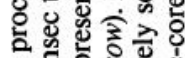
을

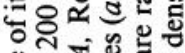

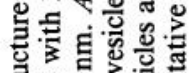
손은 שㄴ

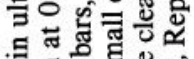
. 造 덩 记

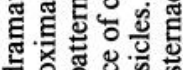
난 현.

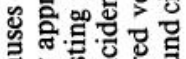

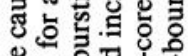
पूँ

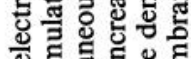

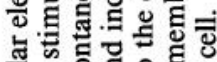
娄 क ฮ ज्ञ

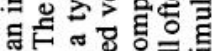
두은

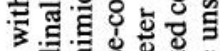

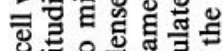
U. 응 可

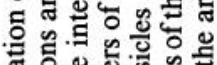

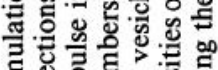

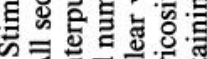
《.

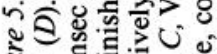

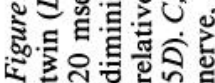



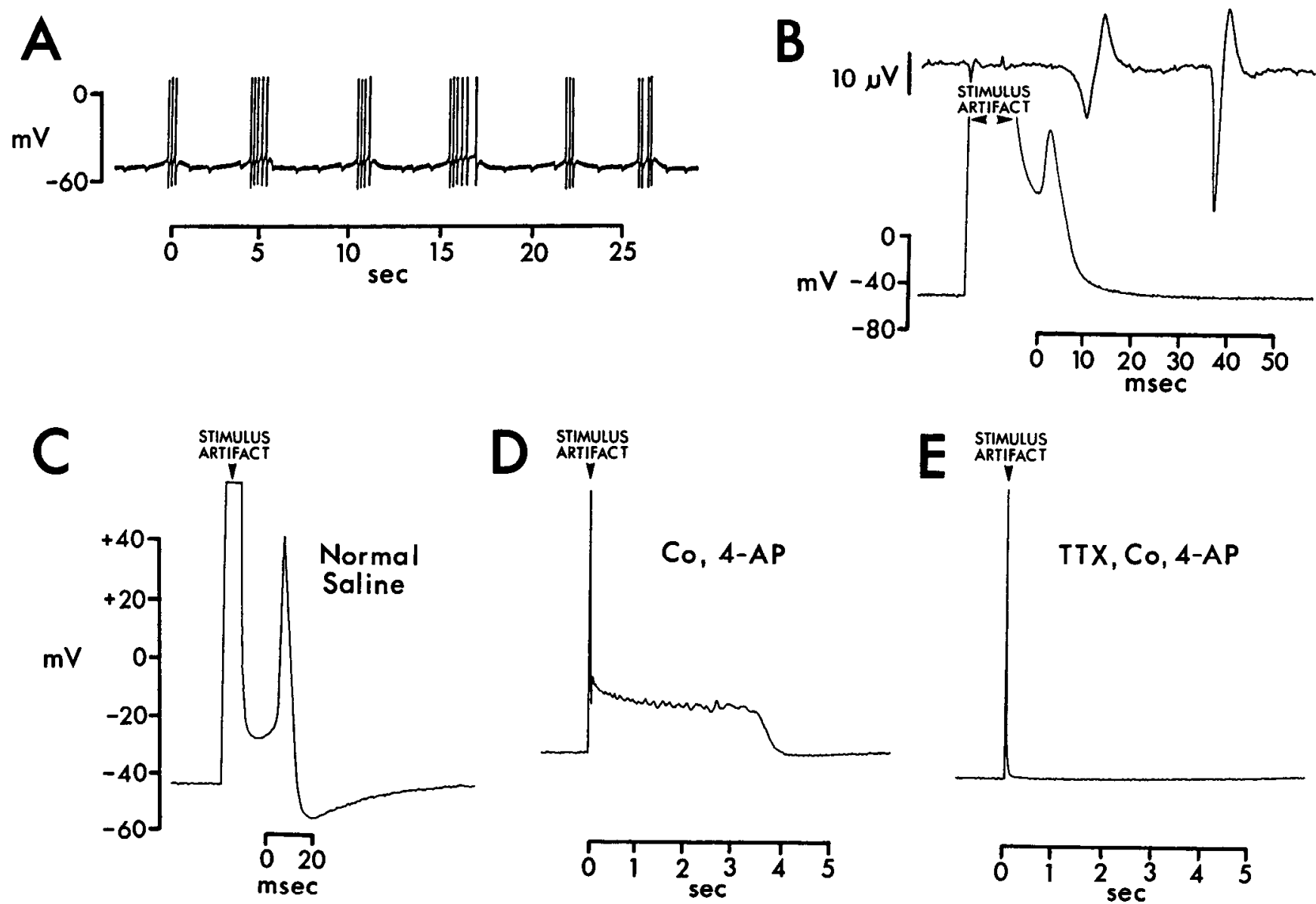

Figure 6. Recordings of spontaneous and evoked responses in current clamp. All intracellular recordings were made intrasomatically. $A$, Example of the spontaneous repetitive bursting, punctuated by IPSPs, seen in many CC cells. $B$, Injection of a brief intracellular depolarizing pulse evokes an intrasomatic spike (lower trace) and a resultant extracellularly recorded spike in the contralateral antennular nerve (upper trace). The extracellular $\mathrm{CC}$ cell spike is significantly longer in duration than a typical non- $\mathrm{CC}$ cell spike recorded just subsequent to it. $C$, Action potential evoked in normal saline by a brief current pulse. $D$, In the presence of $20 \mathrm{~mm}$ Co (Ca-free) and $5 \mathrm{~mm} 4-\mathrm{AP}$, the peak of the action potential is significantly reduced, and a prolonged plateau response is elicited (note change in time scale from $C$ ). $E$, Plateau potential is abolished when $1 \mu \mathrm{M}$ TTX is added to the $\mathrm{Co}, 4-\mathrm{AP}$ saline. Note that the membrane potential becomes less negative in Co/4-AP saline and more negative in TTX. Stimulus was 7 msec and the same amplitude in $C-E$.

TEA-sensitive current which contributes to the net outward current (data not shown) and to the repolarization of the action potential (Stockbridge and Ross, 1986).

4-AP reversibly blocks the early transient outward current in $\mathrm{CC}$ cells (Fig. $8 A$ ) as it does the A-current in molluscan neurons (Thompson, 1977). Like the molluscan A-current, the transient outward current in CC cells may be inactivated: depolarizing steps to a fixed voltage from reduced (depolarized) holding potentials result in inactivation of the outward current (Fig. 8B), which is complete when the cell is stepped to $-40 \mathrm{mV}$ for $1 \mathrm{sec}$ or longer.

\section{Na current}

To attempt to isolate the Na current, we added 4-AP to the saline to block the A-like current and $\mathrm{Co}$ to block inward $\mathrm{Ca}$ currents. In this saline, depolarizing steps still evoke net outward current (Fig. 9A). When TTX is added to this saline, the net outward current increases, indicating that the TTX is blocking an inward component of the current (Fig. 9A). Subtraction of the current obtained in the presence of TTX from that obtained in its absence reveals the isolated inward TTX-sensitive current
(Fig. $9 B$ ). This current sags slightly during the pulse, perhaps due to a very slow inactivation process or to a slow increase in $I_{\mathrm{K}}$.

The dependence of the persistent TTX-sensitive component on voltage (Fig. 9C) was determined from a family of currents measured at "steady state" just before the end of the $1.5 \mathrm{sec}$ pulse. This current activates in this case at approximately -60 $\mathrm{mV}$, a value negative to the normal resting potential of the cell $(-40$ to $-50 \mathrm{mV})$, and consequently is partially activated at rest. While values of activation voltage varied from preparation to preparation, due either to real variation or to a difference in the adequacy of the space clamp, this observation is consistent with that of Figure $7 A$ showing that TTX hyperpolarized the cell. Such a hyperpolarization would be expected if a steady current was blocked by the TTX.

When $[\mathrm{Na}]_{\circ}$ is reduced by $50 \%$, the amplitudes of the persistent currents in a family evoked by depolarizing voltage steps are reduced (Fig. 10). A rough estimate of $E_{\mathrm{Na}}$ in normal saline and in $50 \% \mathrm{Na}$ was made by extrapolating the current-voltage relations taken in the 2 salines. In $50 \% \mathrm{Na}$ there was an approximately $20 \mathrm{mV}$ reduction in $E_{\mathrm{Na}}$, a value close to $17 \mathrm{mV}$ 

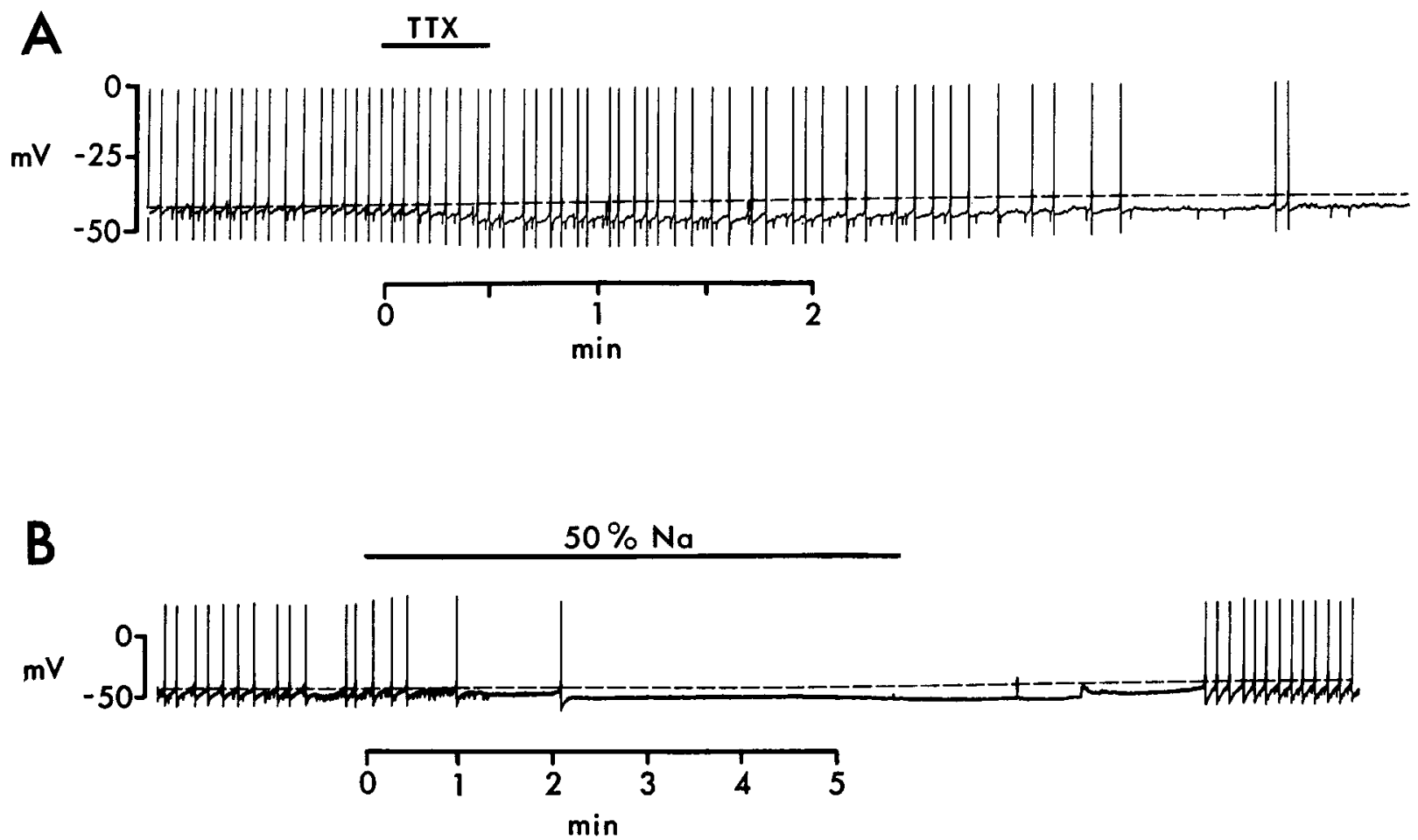

Figure 7. Effect of TTX $(A)$ and $50 \% \mathrm{Na}(B)$ on membrane potential of the CC cell. $A$, Partial, reversible block of activity in the CC cell with TTX leads to a hyperpolarization of the CC cell (here $3-4 \mathrm{mV}$; cf. Fig. $6 C-E$ ). Block was achieved by a 30 sec pulse of TTX (1 $\mu \mathrm{M})$ added to normal saline. The spontaneous action potentials were truncated by the chart recorder and therefore the trace does not reflect their true amplitude. $B, 50 \% \mathrm{Na}$ (substituted with Tris) also hyperpolarizes $(5-6 \mathrm{mV})$ the $\mathrm{CC}$ cell. $A$ and $B$ are from separate cells.

calculated from the Nernst relation. We conclude that the persistent inward current is carried by Na since it is reduced in $50 \% \mathrm{Na}$, is sensitive to TTX, and persists in Co.

The persistent $\mathrm{Na}$ current may also be seen in normal saline (no added Co or 4-AP) by subtracting currents taken in the presence of TTX from those taken in its absence (Fig. 11, $A$ and $B$ ). Small depolarizing steps were used to minimize activation of the initial fast inward currents and also the early transient
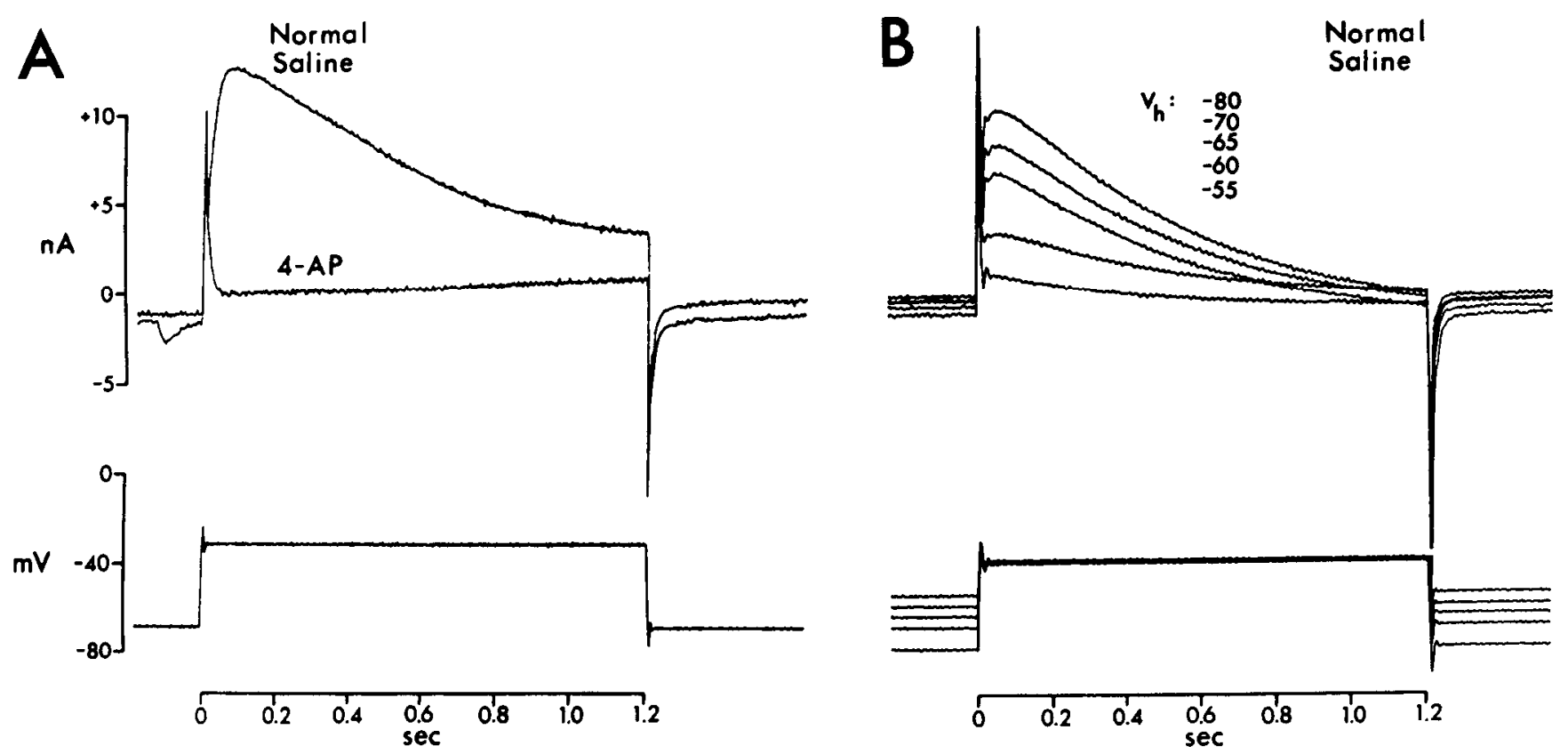

Figure 8. Voltage-clamp records demonstrating the outward current, resembling molluscan A-current, evoked by depolarizing voltage steps. $A$, Depolarizing voltage steps (lower traces) activate an early outward transient current that is reversibly blockable by 5 mM 4-AP. Stronger depolarizing steps than those shown here elicit a pronounced inward current, blockable with Co and TTX. $B$. Stepping to a fixed voltage from increasingly depolarized holding potentials results in inactivation of the $I_{\mathrm{A}}$, which is complete at approximately $-40 \mathrm{mV}$ (not shown). 

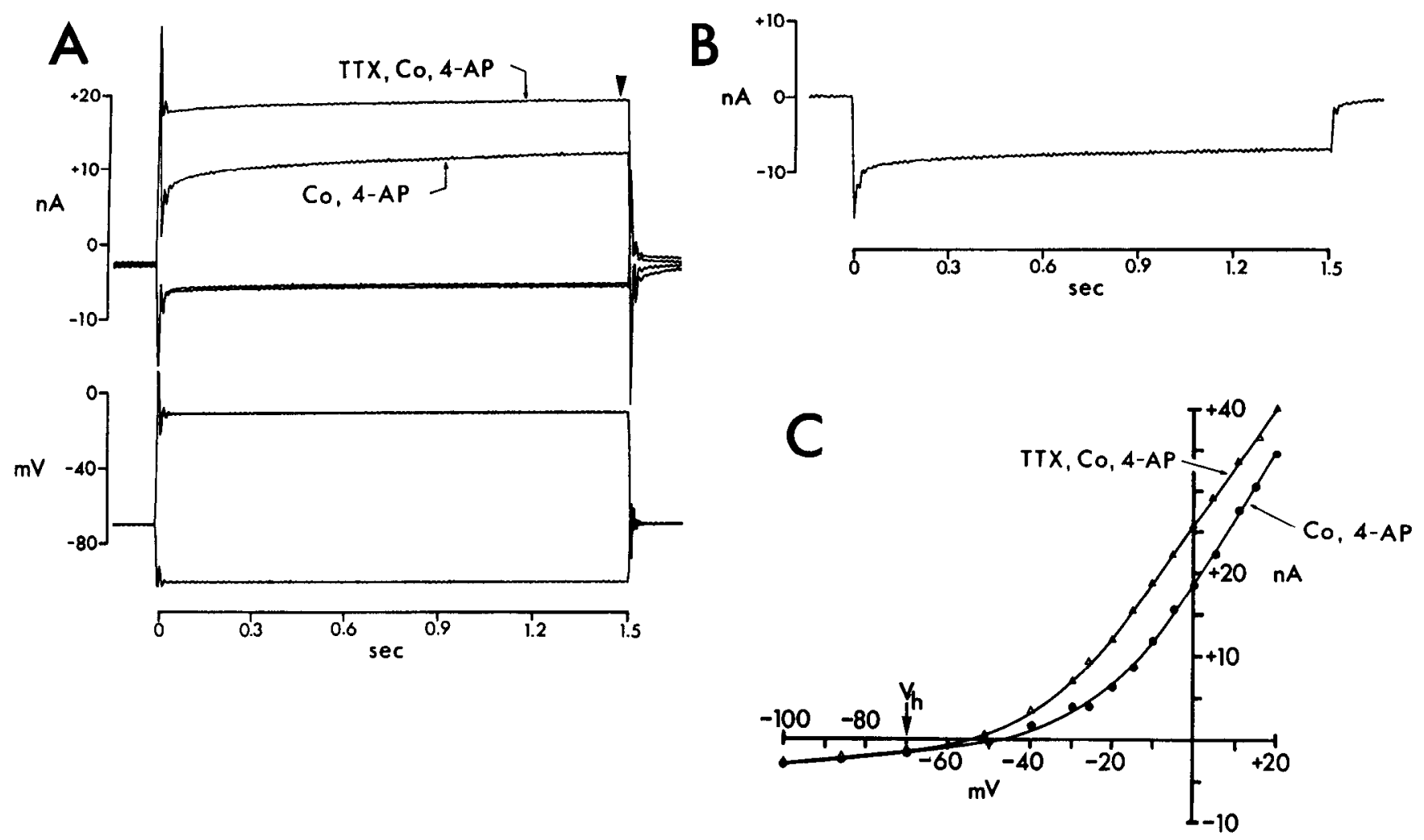

Figure 9. TTX-sensitive, persistent inward current demonstrated by subtraction of currents in the presence of TTX (1 $\mu \mathrm{M})$ from those in its absence. Co (20 mM) and 4-AP (5 mM) were added to the salines to block Ca and early transient outward current. $A$, Currents (upper traces) evoked by voltage steps (lower traces) in the absence and presence of TTX. The net outward current observed in saline containing Co and 4-AP increased when TTX was added. When hyperpolarizing voltage steps were applied, there was little difference between the evoked inward currents in the two salines. Measurements of steady-state currents were made late in the pulse (indicated by arrowhead). $B$, TTX-sensitive, persistent inward current obtained by subtraction of the net outward currents in $A$. C, Current-voltage plot for steady-state currents obtained from the experiment shown in $A . V_{h}$ indicates holding potential.

outward current. The current-voltage relation (Fig. 1lC) shows that this current activates below $-50 \mathrm{mV}$ in normal saline and is therefore finite at the normal resting potential.

\section{Discussion}

Two main points are made by the work presented in this paper. First, ultrastructural observations indicate that $\mathrm{CC}$ cells are neurosecretory and that they release material, packaged in densecored vesicles, into the peripheral (antennular) nerve in which they arborize. Second, voltage-clamp experiments reveal a $\mathrm{Na}$ conductance that is essentially noninactivating and has a voltage threshold negative to the resting potential. Because this conductance is finite at the resting potential, it participates in controlling the level of activity of the cell: When it is partially blocked with TTX or when $E_{\mathrm{Na}}$ is made less positive by reducing $[\mathrm{Na}]_{o}$, the cell hyperpolarizes and changes its firing frequency.

\section{The function of the CC cell}

\section{Is the CC cell neurosecretory?}

Discoveries of recent years have blurred the distinction between a neuron making contact with a postsynaptic target and the classic neurosecretory cell, which releases a (usually aminergic or peptidergic) messenger that affects target cells some distance away (see review by Dismukes, 1979, and appended commentaries). In particular, neurosecretory-like "neuromodulatory cells" may not make a synapse or release messenger into the general circulation, but instead release a molecule that has an immediate, local influence on a number of target cells (Orchard, 1982; Evans and Myers, 1986). The salient features of thc "ncurosecretory" cell remain, first, its lack of a clear postsynaptic target and, second, its large and abundant DCVs. In these respects the CC cell is a neurosecretory cell.

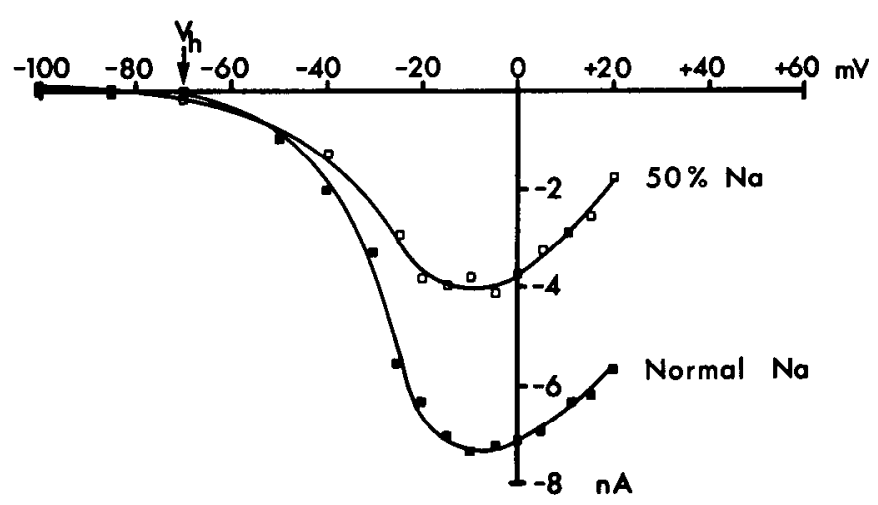

Figure 10. Current-voltage plot for steady-state currents in saline with normal extracellular $\mathrm{Na}$ and in saline with extracellular $\mathrm{Na}$ reduced to $50 \%$ (replaced by Tris). Co and 4-AP were present in both salines to block $\mathrm{Ca}$ and early transient outward current. The TTX-sensitive current was decreased in the $50 \% \mathrm{Na}$ saline. Isolation of the inward $\mathrm{Na}$ current was accomplished by subtraction as in Figure 9. Measurements were made near the end of the $1.5 \mathrm{sec}$ pulse. 

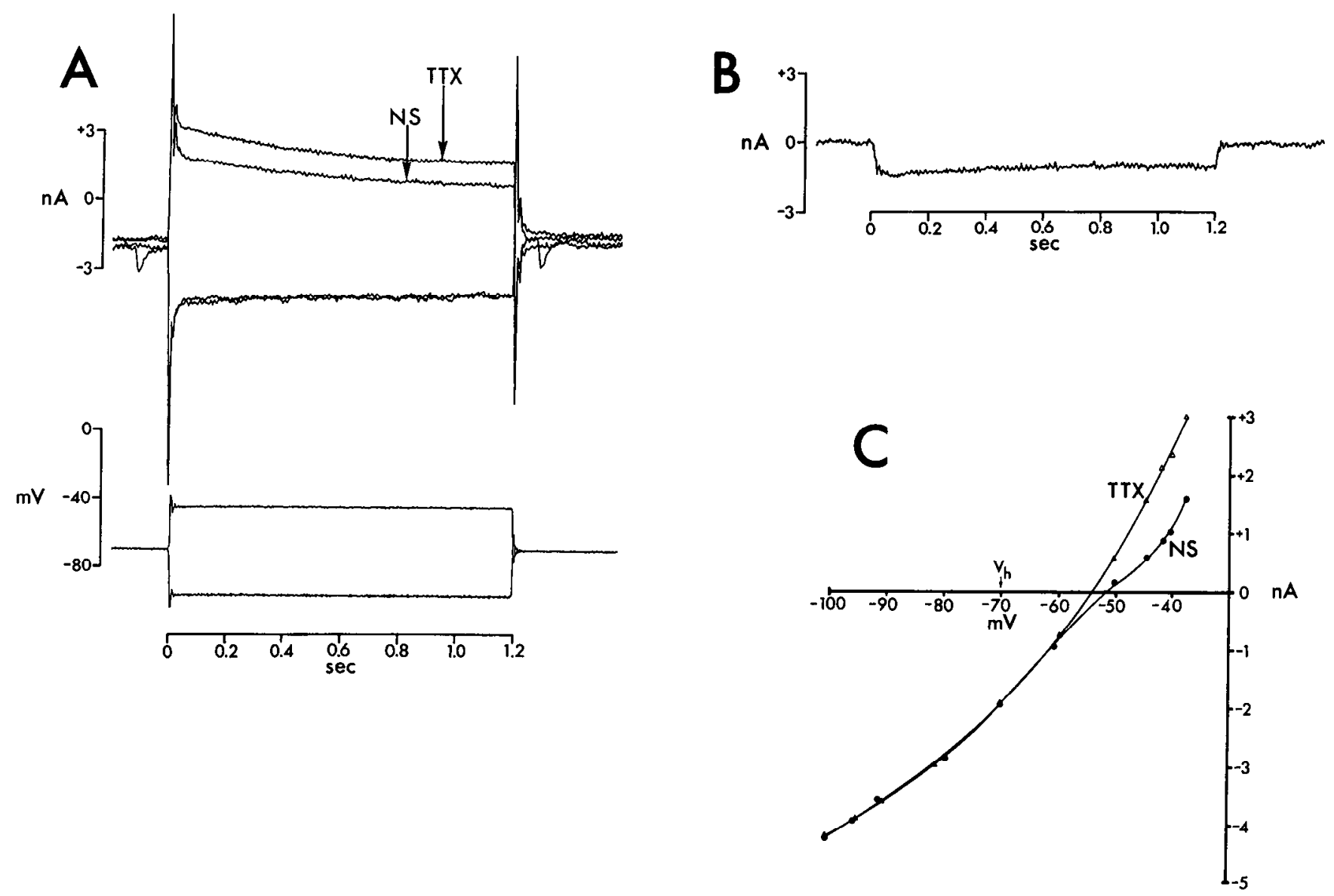

Figure 11. TTX-sensitive persistent current demonstrated by subtraction of currents evoked in normal saline $(N S)$ and TTX (1 $\mu \mathrm{M})$. A, Pair of identical depolarizing and hyperpolarizing steps (lower traces) evoke currents in NS and TTX. Note the increase in the net outward current in TTX compared with NS for the identical depolarizing steps. Downward current deflections before and after the voltage steps are spontaneous events. Partial activation of the early transient outward current is indicated by the sagging current records. $B$, Computer subtraction of the TTX current record from the NS current record for the depolarizing steps shown in $A$, showing the TTX-sensitive current. $C, I / V$ relation for a family of voltage steps including the records shown in $A$. Current values were measured in steady-state just before the end of the step. $V_{h}$ indicates holding potential.

\section{The output processes of the CC cells}

\section{Effect of arbor geometry on the propagating impulse}

It was consistently observed that the extracellularly recorded action potential of the CC cell was considerably broader than other units in the antennular nerve. The cell's extensive meshwork of processes in the nerve might account in part for this observation: The extracellular electrode would be expected to record currents not only from the main processes but from smaller neurites that might conduct impulses out from the main neurite more slowly. The $\mathrm{Ca}$ component of this impulse is also inherently broader than the $\mathrm{Na}$ component in this and other cells (Lewenstein, 1983; Ross et al., 1986; Stockbridge and Ross, 1986); if it were to constitute the major component of the axonal spike, it would also be expected to contribute to the spike's broadness.

The highly branched, varicose axonal tree of the $\mathrm{CC}$ cell presents a load to an impulse propagating down the axon which could potentially cause impulse failure. Ross et al. (1986) have presented evidence for a high density of $\mathrm{Ca}$ channels in the soma, neuropilar and primary axonal processes of the cell that seems to aid the impulse in propagating despite this load. A high density of $\mathrm{Ca}$ channels might also be expected to occur out in the cell's arborization because of the numerous release sites present there. Stockbridge and Ross (1986) have demonstrated that a propagating $\mathrm{Ca}$ spike is the functional correlate of this high $\mathrm{Ca}$ channel density, and it is interesting, as they have noted, that one of the few other instances of a propagating $\mathrm{Ca}$ spike also occurs in an identified neurosecretory cell (Orchard, 1976).

\section{Release of substances from the DCVS at the varicosities}

The varicosities of the unstimulated $\mathrm{CC}$ cell were in many respects similar to those described for another well-studied invertebrate neurosecretory system, the bag cells of Aplysia (Haskins et al., 1981). In both cases DCVs are packed densely in the varicosities, and often appear to be arranged in linear trains as though traveling along distinct intracellular channels, perhaps guided by cytoskeletal elements; omega figures suggestive of possible release sites were seen on rare occasions in each cell type.

The changes in ultrastructure of the CC cell's varicosities seen with stimulation are typical of regions of cells undergoing exocytosis and are similar to those seen in other stimulated neurosecretory cells (e.g., Haskins et al., 1981; see review by Nordmann, 1983). DCVs are reduced in number, and microvesicles, DCVsized electron-lucent vesicles, and larger cisternae become prominent.

We do not know whether an actual numerical increase in the 
microvesicles has occurred or if the clustering simply represents a redistribution of the vesicles. Microvesicles may serve to buffer $[\mathrm{Ca}]_{i}$ by $\mathrm{Ca}$ accumulation and extrusion following stimulationinduced depolarization (Nordmann and Chevallier, 1980; Shaw and Morris, 1980; see review by Nordmann, 1983).

It has been suggested (Nordmann and Morris, 1976; see review by Nordmann, 1983) that an increase in the occurrence of DCV-sized electron-lucent vcsiclcs following stimulation might be associated with endocytotic membrane retrieval. Neurosecretory cells, unlike most neurons, are thought not to recycle endocytosed membrane to form new secretory vesicles in the terminal (Winkler, 1977), but rather to transport this membrane back to their somata, where it is either recycled or broken down (Theodosis, 1982, 1983). It is possible that the large electronlucent vesicles we have observed, particularly in the larger diameter processes, may represent such retrogradely transported membrane.

Heuser and Reese (1979) have noted that large cisternae (similar to those we have observed here) become more abundant in preparations intensely stimulated for prolonged periods. Their precise role in endocytosis, however, remains unclear.

\section{Conductances in the CC cell's membrane}

Possible effect of $K$ and $\mathrm{Na}$ conductances on the cell's activity Most cells of the barnacle's supraesophageal ganglion have a distinctive pattern of impulse and synaptic activity when impaled by a microelectrode. In contrast, the activity patterns of CC cells are quite variable and include near quiescence, steady firing (Fig. 7), or firing in a bursting pattern (Fig. 6A), depending on the cell. The ccll possesses at least two conductances, the transient outward current and the persistent $\mathrm{Na}$ current, which are in a position to influence the firing of the cell because they are likely to be partially activated at the cell's resting potential of -40 to $-50 \mathrm{mV}$.

Transient outward currents with properties similar to the one we report here have been described in a number of preparations (see review by Thompson and Aldrich, 1980) and in particular in certain invertebrate neurons, where they are important in determining the duration of the interspike interval in repetitive firing (Conner and Stevens, 1971; Conner, 1978). The transient outward current described here is similar to the molluscan A-current in that depolarization to a particular potential causes the current first to activate and then to inactivate. Like the A-current, this current is also blocked by 4-AP. In many respects, our current is similar or identical to the A-current seen in other organisms; however, detailed kinetic studies and demonstration of $\mathrm{K}$ ion dependence remain to be done to make this identification certain.

Persistent (or slowly inactivating) $\mathrm{Na}$ conductances have now been described in a diversity of neurons: stretch receptors (Grampp and Sjölin, 1975; Gestrelius et al., 1981); giant neurons of Aplysia (Colmers et al., 1982); frog (Dubois and Bergman, 1975), squid (Shoukimas and French, 1980; Matteson and Armstrong, 1982), and cockroach axons (Yawo et al., 1985); cerebellar Purkinje neurons (Sugimori and Llinás, 1983); cortical (Stafstrom et al., 1985), neocortical (Connors et al., 1982) and thalamic neurons (Jahnsen and Llinás, 1984); hippocampal pyramidal cells (French and Gage, 1985), and even frog muscle (Almers et al., 1983). In many of these cases, the cells either fire spontaneously in repetitive fashion or can be induced to fire repetitively when stimulated. In most of these reports it has been suggested that the activation of a persistent Na conductance could be important in controlling the rate of repetitive firing.

Since TTX or $50 \% \mathrm{Na}$ changed the firing rate of an active CC cell, the persistent $\mathrm{Na}$ conductance may play a similar role in this cell type. This function is reasonable for the $\mathrm{CC}$ cells since the persistent Na current, partially activated at rest, is strongly activated in the range of membrane potentials where repetitive firing occurs.

In cells that burst, the depolarizing phase of the bursting pacemaker potential has been attributed to persistent, slowly inactivating $I_{\mathrm{Na}}$ or $I_{\mathrm{Ca}}$ or both (Johnston, 1976; Barker and Smith, 1978; Gorman et al., 1982). It is possible that CC cells rely on inactivation of the $I_{\mathrm{A}}$ and/or activation of the persistent $\mathrm{Na}$ current for the generation of the depolarization underlying their bursts. The current(s) responsible for repolarization of the dcpolarized burst potential in $\mathrm{CC}$ cells has not yet been determined.

Evidence for a diversity of $\mathrm{Na}$ channels is now beginning to appear based on differential sensitivity to TTX and other neurotoxins, immunological studies, etc. (Barchi, 1987). Na channels with fast (a few msec), slow (msec-sec), and ultraslow (min or more) inactivation have been described (e.g., Hodgkin and Huxley, 1952; Rudy, 1981; Almers et al., 1983), but these channels are not necessarily different types: Patlak and Ortiz (1986) have found that the same $\mathrm{Na}$ channel in frog muscle can give rise to transient early currents and to persistent or "late" currents.

In some preparations, persistent $\mathrm{Na}$ currents are partially activated at rest (e.g., French and Gage, 1985, and in CC cells), while in others, the activation voltage for the current seems to bc at a somewhat depolarized value with respect to the resting potential (e.g., Stafstrom et al., 1985). Differences in threshold would be expected to produce differences in the precise function of the current. In the squid axon, a small population of $\mathrm{Na}$ channels that activate at low threshold but have slow closing kinetics (relative to the classical fast channels) has been described (Gilly and Armstrong, 1984); it has been suggested that their function may be to trigger the action potential. These "threshold channels," though only a small percentage of the total $\mathrm{Na}$ permeability, may thus play an important role in the control of firing frequency. Low-threshold Na channels, particularly if they are active at rest and do not inactivate over seconds or minutes, would seem to be in a unique position to control the cell's firing pattern particularly for long-duration burst periods. It is an intriguing possibility that neurotransmitters or neuromodulators could conceivably regulate this channel and thus exert dramatic effects on the activity of the cell (see Barker and Smith, 1978).

\section{Might the persistent Na current affect release?}

A number of studies indicate that an increase in $[\mathrm{Na}]_{\mathrm{i}}$ can augment transmitter release by inducing translocation of $\mathrm{Ca}$ from internal stores, thereby increasing [Ca $]_{i}$ (Lowe et al., 1976; LevTov and Rahamimoff, 1980; Melinek et al., 1982; Atwood et al., 1983). Perhaps the persistent $\mathrm{Na}$ conductance of this cell leads to a higher $[\mathrm{Na}]_{\mathrm{i}}$ and, through translocation, a higher resting $[\mathrm{Ca}]_{i}$, which increases the effectiveness of the $\mathrm{Ca}$ that enters during the action potential. Although we have no evidence that the persistent $\mathrm{Na}$ channel is located at the release sites in the $\mathrm{CC}$ cell, recordings from peptidergic neurosecretory terminals in the sinus gland of crustaceans suggest the presence of channels similar to those described here (see Fig. 11 in Nagano and Cooke, 
1987). A possible effect of the Na current on release should be testable if either the released compound or a cell postsynaptic to the $\mathrm{CC}$ cell in the ganglion is identified.

\section{References}

Almers, W., P. R. Stanfield, and W. Stühmer (1983) Slow changes in currents through sodium channels in frog muscle membrane. J. Physiol. (Lond.) 339: 253-271.

Atwood, H. L., M. P. Charlton, and C. S. Thompson (1983) Neuromuscular transmission in crustaceans is enhanced by a sodium ionophore, monensin, and by prolonged stimultion. J. Physiol. (Lond.) 335: 179-195.

Bacon, J. P., and J. S. Altman (1977) A silver intensification method for cobalt-filled neurones in wholemount preparations. Brain Res. 138: 359-363.

Barchi, R. L. (1987) Sodium channel diversity: Subtle variations on a complex theme. TINS 10: 221-223.

Barker, J. L., and T. G. Smith, Jr. (1978) Electrophysiological studies of molluscan neurons generating bursting pacemaker potential activity. In Abnormal Neuronal Discharges, N. Chalazonitas and M. Boisson, eds., pp. 359-387, Raven, New York.

Chaigneau, J. (1983) Neurohemal organs in crustacea. In Neurohemal Organs of Arthropods, A. P. Gupta, ed., pp. 53-89, Thomas, Springfield, IL.

Colmers, W. F., D. V. Lewis, Jr., and W. A. Wilson (1982) Cs+ loading reveals $\mathrm{Na}^{+}$-dependent persistent inward current and negative slope resistance region in Aplysia giant neurons. J. Neurophysiol. 48: 11911200.

Conner, J. A. (1978) Slow repetitive activity from fast conductance changes in neurons. Fed. Proc. 36: 2139-2145.

Connor, J. A., and C. F. Stevens (1971) Voltage clamp studies of a transient outward current in gastropod neural somata. J. Physiol. (Lond.) 213: 21-30.

Connors, B. W., M. J. Gutnick, and D. A. Prince (1982) Electrophysiological properties of neocortical neurons in vitro. J. Neurophysiol. 48: 1302-1320.

Davis, R. E., and A. E. Stuart (1985) A prolonged, TTX-sensitive sodium current in a putative neurosecretory cell of the barnacle. $J$. Gen. Physiol. 86: 19a.

Davis, R. E., and A. E. Stuart (1986) An unusual sodium channel in identified neurons of the barnacle. Soc. Neurosci. Abstr. 12: 43.

Dismukes, R. K. (1979) New concepts of molecular communication among neurons. Behav. Brain Sci. 2: 409-448.

Dubois, J. M., and C. Bergman (1975) Late sodium current in the node of Ranvier. Pfluegers Arch. 357: 145-148.

Evans, P. D., and C. M. Myers (1986) Peptidergic and aminergic modulation of insect skeletal muscle. J. Exp. Biol. 124: 143-176.

Finkel, A. S., and S. J. Redman (1985) Optimal voltage clamping with single microelectrode. In Voltage and Patch Clamping with Microelectrodes, T. G. Smith, H. Lecar, S. J. Redman, and P. W. Gage, eds., pp. 95-120. American Physiological Society, Bethesda, MD.

French, C. R., and P. W. Gage (1985) A threshold sodium current in pyramidal cells in rat hippocampus. Neurosci. Lett. 56: 289-293.

Gestrelius, S., W. Grampp, and L. Sjölin (1981) Subthreshold and near-threshold membrane currents in lobster stretch receptor neurones. J. Physiol. (Lond.) 310: 191-203.

Gilly, W. M., and C. M. Armstrong (1984) Threshold channels-a novel type of sodium channel in squid giant axon. Nature $309: 448-$ 450.

Gorman, A. L. F., A. Hermann, and M. V. Thomas (1982) Ionic requirements for membrane oscillations and their dependence on the calcium concentration in a molluscan pacemaker neurone. J. Physiol. (Lond.) 327: 185-217.

Grampp, W., and L. Sjölin (1975) Subthreshold membrane currents in slowly adapting stretch receptor neurone of lobster. Nature 257: $697-698$.

Gupta, A. P. (1983) Neurohemal and neurohemal-endocrine organs and their evolution in arthropods. In Neurohemal Organs of Arthropods, A. P. Gupta, ed., pp. 17-50, Thomas, Springfield, IL.

Haskins, J. T., C. H. Price, and J. E. Blankenship (1981) A light and electron microscopic investigation of the neurosecretory bag cells of Aplysia. J. Neurocytol. 10: 729-747.

Heuser, J. E., and T. S. Reese (1979) Synaptic-vesicle exocytosis captured by quick-freezing. In The Neurosciences Fourth Study Program,
F. O. Schmitt and F. G. Worden, eds., pp. 573-600, MIT Press, Cambridge, MA.

Hille, B. (1984) Ionic Channels of Excitable Membranes, Sinauer, Sunderland, MA.

Hodgkin, A. L., and A. F. Huxley (1952) The dual effect of membrane potential on sodium conductance in the giant axon of Loligo. J. Physiol. (Lond.) 116: 497-506.

Hudspeth, A. J., and A. E. Stuart (1977) Morphology and responses to light of the somata, axons, and terminal regions of individual photoreceptors of the giant barnacle. J. Physiol. (Lond.) 272: 1-23.

Jahnsen, H., and R. Llinás (1984) Ionic basis for the electroresponsiveness and oscillatory properties of guinea-pig thalamic neurones in vitro. J. Physiol. (Lond.) 349: 227-247.

Johnston, D. (1976) Voltage clamp reveals basis for calcium regulation of bursting pacemaker potentials in Aplysia neurons. Brain Res. 107: $418-423$.

Lev-Tov, A, and R. Rahamimoff (1980) A study of tetanic and posttetanic potentiation of miniature end-plate potentials at the frog neuromuscular junction. J. Physiol. (Lond.) 309: 247-273.

Lewenstein, L. A. (1983) Propagating calcium spikes in identified cells in the supraesophageal ganglion of the giant barnacle, Balanus nubilus. Biol. Bull. 165: 529 .

Lowe, D. A., B. P. Richardson, P. Taylor, and P. Donatsch (1976) Increasing intracellular sodium triggers calcium release from bound pools. Nature 260: 337-338.

Matteson, D. R., and C. M. Armstrong (1982) Evidence for a population of sleepy sodium channels in squid axon at low temperature. J. Gen. Physiol. 79: 739-758.

Melinek, R., A. Lev-Tov, H. Meiri, S. D. Erulkar, and R. Rahamimoff (1982) Regulatory role of intracellular sodium ions in neurotransmitter secretion. Isr. J. Med. Sci. 18: 37-43.

Nagano, M., and I. M. Cooke (1987) Comparison of electrical responses of terminals, axons, and somata of a peptidergic neurosecretory system. J. Neurosci. 7: 634-648.

Neher, E. (1971) Two fast transient current components during voltage clamp on snail neurones. J. Gen. Physiol. 58: 36-53.

Nordmann, J. J. (1983) Stimulus-secretion coupling. In The Neurohypophysis: Structure, Function and Control, Progress in Brain Research, Vol. 60, B. A. Cross and G. Leng, eds., pp. 281-304, Elsevier, Amsterdam.

Nordmann, J. J., and J. Chevallier (1980) The role of microvesicles in buffering [Ca] in the neurohypophysis. Nature 287: 54-56.

Nordmann, J. J., and J. F. Morris (1976) Membrane retrieval at neurosecretory axon endings. Nature 261: 723-725.

Orchard, I. (1976) Calcium dependent action potentials in a peripheral neurosecretory cell of the stick insect. J. Comp. Physiol. 112: 95-102.

Orchard, I. (1982) Octopamine in insects: Neurotransmitter, neurohormone, and neuromodulator. Can. J. Zool. 60: 659-669.

Orchard, I., and B. G. Loughton (1985) Neurosecretion. In Comprehensive Insect Physiology, Biochemistry, and Pharmacology, Vol. 7, G. A. Kerkut and L. I. Gilbert, eds., pp. 61-107, Pergamon, New York.

Patlak, J. B., and M. Ortiz (1986) Two modes of gating during late $\mathrm{Na}^{+}$channel currents in frog sartorius muscle. J. Gen. Physiol. 87 : 305-326.

Phillips, C. E. (1980) Intracellularly injected cobaltous ions accumulate at synaptic densities. Science 207: 1477-1479.

Price, C. H., and D. J. McAdoo (1979) Anatomy and ultrastructure of the axons and terminals of neurons R3-R14 in Aplysia. J. Comp. Neurol. 188: 647-678.

Ross, W. N., L. L. Stockbridge, and N. L. Stockbridge (1986) Regional properties of calcium entry in barnacle neurons determined with $\mathrm{Ar}$ senazo III and a photodiode array. J. Neurosci. $6: 1148-1159$.

Rudy, B. (1981) Inactivation in Myxicola giant axons responsible for slow and accumulative adaptation phenomena. J. Physiol. (Lond.) 312: $531-549$.

Sedlak, B. J. (1985) Structure of endocrine glands. In Comprehensive Insect Physiology, Biochemistry, and Pharmacology, Vol. 7, G. A. Kerkut and L. I. Gilbert, eds., pp. 25-60, Pergamon, New York.

Shaw, F. D., and J. F. Morris (1980) Calcium localization in the rat neurohypophysis. Nature $287: 56-58$.

Shoukimas, J. J., and R. J. French (1980) Incomplete inactivation of sodium currents in nonperfused squid axon. Biophys. J. 32: 857-862.

Stafstrom, C. E., P. C. Schwindt, M. C. Chubb, and W. E. Crill (1985) Properties of persistent sodium conductance and calcium conductance 
of layer $\mathrm{V}$ neurons from cat sensorimotor cortex in vitro. J. Neurophysiol. 53: 153-170.

Stockbridge, L. L., and W. N. Ross (1986) A TTX-resistant propagating calcium action potential. J. Neurophysiol. 56: 1669-1679.

Sugimori, M., and R. Llinás (1983) Voltage clamping of Purkinje cells in vitro: A study in guinea pig cerebellar slices. Soc. Neurosci. Abstr. 9: 681 .

Theodosis, D. T. (1982) Secretion-related accumulation of horseradish peroxidase in magnocellular cell bodies of the rat supraoptic nucleus. Brain Res. 233: 3-16.

Theodosis, D. T. (1983) Intracellular membrane movements associated with hormone release in magnocellular neurones. In The Neurohypophysis: Structure, Function and Control, Progress in Brain Research, Vol. 60, B. A. Cross and G. Leng, eds., pp. 273-279, Elsevier, Amsterdam.

Thompson, S. H. (1977) Three pharmacologically distinct potassium channels in molluscan neurones. J. Physiol. (Lond.) 265: 465-488.
Thompson, S. H., and R. W. Aldrich (1980) Membrane potassium channels. In The Cell Surface and Neuronal Function, C. W. Cotman, G. Poste, and G. L. Nicolson, eds., pp. 50-85, North-Holland, New York.

Tyrer, N. M., and E. M. Bell (1974) The intensification of cobalt-filled neurone profiles using a modification of Timm's sulfide-silver method. Brain Res. 73: 151-155.

Wilson, W. A., and M. M. Goldner (1975) Voltage clamping with a single microelectrode. J. Neurobiol. 6: 411-422.

Winkler, H. (1977) The biogenesis of adrenal chromaffin granules. Neuroscience 2: 657-683.

Yawo, H., H. Kojima, and M. Kuno (1985) Low-threshold, slowinactivating $\mathrm{Na}^{+}$potentials in the cockroach giant axon. J. Neurophysiol. 54: 1087-1100. 